ISMC 2021

$16^{\text {th }}$ International Strategic Management Conference

\title{
THE ROLE OF SOCIAL NETWORKS ON BUILDING ORGANIZATIONAL STRATEGIC PARTNERS
}

\author{
Abdikarim Mohaidin Ahmed (a), Şule Erdem Tuzlukaya (b), Erdem Kırkbeşoğlu (c)* \\ *Corresponding author \\ (a) Atılım University, Kızılcaşar, 06830 Gölbaşı, Ankara, Turkey, muhudiin@gmail.com \\ (b) Atılım University, Kızılcaşar, 06830 Gölbaşı, Ankara, Turkey, sule.tuzlukaya@atilim.edu.tr \\ (c) Başkent University, Eskisehir Yolu 18.km Etimesgut, Ankara, Turkey, erdemk@baskent.edu.tr
}

\begin{abstract}
Organizations are entities embedded in the social structures, their position within a wider structure will have a serious effect on their performance. The organization's network relationship usually represents a critical path of securing the necessary resources so that organizations can grow and survives. Resources are also critically needed so that organizations can survive and grow in uncertain environments. The executive's social network will have a positive impact on organizations' access to resources whereby it opens doors for potential opportunities and pushes performance. However, building organizational strategic partners is usually influenced by the working experience of the executives. The aim of this paper is to examine the influence of executives' social networks on building organizational strategic partners in the context of least developed countries. This study will question to what extent the international experience and the heterogeneity of the executives' social network influence building organizations' strategic partners. A multiple case study design has been utilized. The findings of the study revealed that international experience and heterogeneity of the executives' social network will have influences on building organizational strategic partners.
\end{abstract}

2357-1330 (c) 2021 Published by European Publisher.

Keywords: Resource dependency theory, social network theory, strategic partners 


\section{Introduction}

Heimovics et al. (1993), argue that the focus of the executive should concern the constant environmental changes that are surrounding the organization which threatens its existence or shows new developmental opportunities. individual ties with similar characteristics such as functional background may likely facilitate the exchange of support (McDonald \& Westphal, 2003). Individual connections may facilitate or provide channels for information exchange and transmission of ideas, knowledge, and experience (El-Khatib et al., 2015). Acquiring critical and potential resources usually tend to be embedded in a person's network whereby organizations can develop new network alliances with the help of such a person's experience (Ahn et al. 2009). Milanzi (2012), argue that Social networks are usually valuable sources of information that are related to the opportunities as well as ideas of new business. Executives with international exposure possess better perspectives, knowledge, experience, and network ties (Ancona \& Caldwell, 1992; Lee \& Park, 2008).

In contrast to the developed countries, social network analysis has not been applied in sub-Saharan African. Current studies mainly focused on social networks and their impact on kinship, the status of health, or social networks, and its role in coping with vulnerability (Walther, 2014). In the context of Somalia, after the state collapse in 1991, the private sector stepped in to fill the gap although they were hampered by limited access to liquidity and lack of opportunities (Berg, 2016). With the absence of a formal financial system in Somalia, a limited number of Somali banks have established strategic partners with other international banks and financial institutions. Scholars had not given attention to the analysis of Somalia's trade networks and in particular to the banking industry.

This paper aims at examining the influence of executives' social networks on building organizational strategic partners. This study will question to what extent the international experience of the executives influences building organizations' strategic partners. Moreover, the study will examine the effect of the heterogeneity of the executives' social network on building ties with potential partners.

\section{Literature Review}

\subsection{Executive Social Network}

Social network theory stresses networks as cognitive structures looking at the minds of members in the organization as well as opportunity structures that can limit or facilitate the actions to be taken (Balkundi \& Kilduff, 2006). The social network theory is based on the notion that the patterns of the social ties that actors are embedded have vital consequences (Freeman, 2004). Such social ties may allow and facilitate access to resources and quick transfer of knowledge and best practices among connected organizations as well as individuals. This will ultimately enable organizations and/or individuals to exploit the opportunities accordingly (Geletkanycz et al., 2001; Gulati et al., 2002; Knoke \& Yang, 2019; Waddock, 1989).

Kirchmaier and Stathopoulos (2008) argue that social networks usually improve the flow of information among peers, and thus the exchange of know-how will reduce asymmetries of information among organizations. Since the social network approach may facilitate the exchange of information that is 
related to exploiting new opportunities, it will give the executives the chance to improve organizations' performance by innovating new products or increase their competitive position by adding features to the existing products (Kirchmaier \& Stathopoulos, 2008). The executive's social network will have a positive impact on organizations' access to resources whereby it opens doors for potential opportunities and promotes enterprise innovation. Acquiring critical and potential resources usually tend to be embedded in a person's network whereby organizations can develop new network alliances with the help of such a person's experience (Barnir \& Smith, 2002; Fernández-Pérez et al.; 2012; Zhang, 2019).

In the context of the social network, the organization's executives may often involve their social networks just to secure the resources that are necessary for an organization to emergence (Ahn et al., 2009). Individual connections may facilitate or provide channels for information exchange and transmission of ideas, knowledge, and experience (El-Khatib et al., 2015). Experienced executives will look for strategic partners with financial resources to ensure the sustainability of their business and enable it to grow fast (Cavusgil, 1998).

The personal network ties of the organization's executives were built upon their previous experiences which they obtained while they worked with other organizations and met with co-workers. According to Okello Candiya Bongomin et al. (2018), the strong connections between individuals can enhances the flow of resources and information. The international experience of the executives is a critical success factor in developing international networks (Daily et al., 2000). For this article, the International experience is the executive prior work at international banks outside Somalia.

\subsection{Executives' social network and building organizational strategic partners in Somalian Context}

The resource dependency theory implies that organizations should frequently collaborate and work with other similar organizations to function and survive within environments characterized by scare resources (Sapat et al., 2019). The theory is based upon the assumption that organizations can assess, understand, and quickly adapt to the environment. However, there may be other factors that can affect the organization to comprehend and adapt to the environment. Organizations are entities embedded in the social structures hence, the organization's position within this wider structure will have a serious effect on its performance (Essman, 2015).

The organization's network relationship usually represents a critical path of securing the necessary resources so that organizations can grow and survives. As per the literature, the newly established organizations tend to face difficulties in establishing relations. However, if they succeed in developing their social network, they can obtain legitimacy and easily overcome the liability of adolescence (Ahn et al., 2009). The social network and resource dependency theories are related as they complement each other. Resource dependency theory argues that organizations are dependent on other organizations through the exchange of resources (Pfeffer \& Salancik, 1978; Heimovics et al., 1993; Davis \& Cobb, 2010; Harkins \& Forster, 2014). The network theory argues that connections are important since it waves path the access to necessary resources for organizations to survive (Jenssen \& Koenig, 2002). The Social network theory is meant to facilitate the formation of a strategic alliance since it will enlarge the circle of potential partners that are trustworthy. 
Since the collapse of Somalia in 1991 and the subsequent civil war, private sector led by the financial institutions has stepped in to fill the gap. The entrepreneurial spirit of Somalia's private banks has safeguarded many lives by facilitating money transfer from relatives who lived in Europe and America to those left behind in the country. However, these financial institutions were seriously hampered by lack of opportunities and limited access to international support. Although access to capital is scarce in sub-Saharan Africa as per the argument of McKinsey, this reality is even felt more in Somalia (Von Berg, 2016). To address this issue, financial institutions establish ties with potential and strategic partners throughout the network of their executives. According to the network theory, connections are important since it waves path the access to necessary resources for organizations to survive (Jenssen \& Koenig, 2002). However, the establishment of business ties with other organizations is usually influenced by the working experience of the management team and the level of position they held so far (Gall \& Schroder, 2006). Based on this assumption, we postulated the following proposition:

Proposition 1: Organizations should acquire executives with international exposure to establish relations with strategic partners.

The heterogeneity of the executives' social networks may be beneficial to organizations since it will support creativity and innovation. Studies suggest that there is a direct link between the heterogeneity of the executives' social networks and organizations' performance. For instance, Fang, Francis, and Hasan (2012) argue that the more heterogeneous is the executives' social network the more they obtain broader information and knowledge and thus compare a range of options and discover further opportunities. For this article, the heterogeneity of the executives is defined as their linkage with a legal institution such as central bank, international banks, and regional bank networks. Accordingly, we postulated the following proposition:

Proposition 2: Organizations should acquire executives with a heterogeneous social network to establish relations with strategic partners.

\section{Methodology}

\subsection{Data Collection}

This paper aims at explaining the effects of the executive's social network on building organizational strategic partners. With the explanatory nature, a qualitative case study will be the preferred research design. To better understand $t$ the phenomenon, a multiple case study design has been utilized, with four different Somalia commercial banks being the cases.

In the study, unstructured interview technique and secondary data was used to analyse the cases. Biography analyses as well as Interviews with executives are the major sources in the case study. However, the websites of the banks, social media accounts, presentations, and other forms of documents have been used when deemed relevant. Within the aim of comparing and contrasting the perspectives and views of the case companies, each case is presented separately.

The unit of analysis in this study is limited to the private commercial banks in Somalia. The international experience of the executives in these banks as well as the heterogeneity of their social network will be the primary concern of this study. The banks are categorized into newly established ones 
with modern banking services and old banks which do not have these services. A deductive method is utilized as the framework of this study whereby propositions have been postulated and tested based on the study results from the collected data. Table 1 shows the descriptive characteristics of the sample.

Table 1. Descriptive Information of the Sample

\begin{tabular}{|c|c|c|c|c|}
\hline Banks & $\begin{array}{c}\text { Year } \\
\text { Founded }\end{array}$ & Services and Products & International Partners & $\begin{array}{l}\text { Heterogeneity of } \\
\text { the executive's } \\
\text { Social Network }\end{array}$ \\
\hline $\begin{array}{l}\text { Dahabshiil } \\
\text { International } \\
\text { Bank }\end{array}$ & 1970 & $\begin{array}{l}\text { fund transfer, retail banking, } \\
\text { corporate banking, online } \\
\text { banking, mobile banking }\end{array}$ & $\begin{array}{c}\text { China Agricultural } \\
\text { Bank, Bank of China, } \\
\text { Actif Bank, Kenya } \\
\text { National Bank, Alnor } \\
\text { Bank }\end{array}$ & $\begin{array}{l}\text { Locally well } \\
\text { connected }\end{array}$ \\
\hline Amal Bank & 1998 & $\begin{array}{c}\text { retail banking, corporate } \\
\text { banking, institutional } \\
\text { banking, diaspora banking, } \\
\text { microfinance banking, online } \\
\text { banking }\end{array}$ & $\begin{array}{c}\text { Established } \\
\text { international } \\
\text { partnership but not } \\
\text { willing to reveal the } \\
\text { names }\end{array}$ & $\begin{array}{l}\text { Locally well } \\
\text { connected }\end{array}$ \\
\hline $\begin{array}{c}\text { International } \\
\text { Bank of Somalia }\end{array}$ & 2013 & $\begin{array}{l}\text { retail and corporate banking, } \\
\text { trade finance, investment } \\
\text { finance, mortgages, swift } \\
\text { transfer, international debit } \\
\text { cards, online banking, ATM } \\
\text { services }\end{array}$ & $\begin{array}{l}\text { Union of Arab banks, } \\
\text { Deloitte, Visa Card, } \\
\text { MasterCard as } \\
\text { principle level }\end{array}$ & $\begin{array}{l}\text { Internationally and } \\
\text { Locally well } \\
\text { connected }\end{array}$ \\
\hline Premier Bank & 2013 & $\begin{array}{c}\text { retail and corporate banking, } \\
\text { mobile banking, internet } \\
\text { banking, ATM services, swift } \\
\text { transfers, international debit } \\
\text { cards }\end{array}$ & $\begin{array}{l}\text { Connected with } \\
\text { Mastercard through } \\
\text { their switch, visa card }\end{array}$ & $\begin{array}{l}\text { Internationally and } \\
\text { Locally well } \\
\text { connected }\end{array}$ \\
\hline
\end{tabular}

\subsection{Case}

Case 1 - Dahabshiil International Bank: According to Mr. Halane, he has been in the banking industry for more than 10 years. He worked with Salaam Somali Bank heading the Accounting Department, Marketing and PR department, as well as the Investment and International Relations Department. Mr. Halane moved to Dahabshiil Bank In July 2012 as the manager of the Mogadishu division. He is now the regional manager of Dahabshiil International Bank. Within his tenure as the Regional Manager of Dahabshiil International Bank, he becomes the Chairman of the Somali Bankers Association (SBA).

Mr. Halane once becomes the Chairman of the Somali Bankers Association, therefore he has a strong connection with the Association. Mr. Halane is not a member of any professional groups within the banking industry but he has established good connections with the authority of Somalia's central bank. Mr. Halane pays a lot of effort to establish relationships between DBI with strategic partners. However, establishing relations with the strategic partners in the context of Somalia is a very difficult task since international banks perceive Somalia as a failed nation, even though Somali Banks comply with the international standards like AML, CFT, and KYC.

Case 2 - Amal Bank: According to Mr. Shire, he has been in the field of financial services for almost 10 years both in Somalia and outside Somalia. He stated that his main responsibility has been the 
CEO of the bank is to establish relations with strategic partners therefore fifty percent of his time is dedicated to network building.

Mr. Shire has stated that he is a member of several financial professional entities but he is not willing to share their names. He has close professional relations with the central bank of Somalia as a regulatory body. Mr. Shire argues that building strategic partners in the context of banking in Somalia is challenging since the Central Bank of Somalia is not functioning fully. He adds that the Judiciary system of Somalia is not trusted by the international partners thereby causing a challenge to the relationship building. Moreover, the image of Somalia as a country needs to be built whereby lots of emphases are given to the security, personal identifications, effective and strong systems.

Case 3 - International Bank of Somalia: According to Mr. Ahmed, he has been in the banking industry for more than 17 years of banking experience having worked with global banks such as Barclays and Standard Chartered in different capacities. Mr. Ahmed had the opportunity to work across different markets such as Kenya, Somalia, UAE, and South Africa under different capacities and in different segments. He was the Managing Director of Premier Bank before he joined IBS as their CEO.

Mr. Ahmed was part of the pioneering team that initiated the idea of having a banker association where banks would share their common issues to find unified solutions. He has close contacts with the Kenya Bankers Association (KBA) and also Bahrain's bankers' association. Mr. Ahmed is a member of the Kenya Bankers Association and KASNEB (Kenya Accountants and Secretaries National Examinations Boars). As the regulator body, Mr. Ahmed maintains a close and professional relationship with the key departments of the central bank of Somalia such as the supervision and licensing department and the Governor and Deputy Governor's offices. Mr. Ahmed highlighted the importance of maintaining relationships with foreign banks to facilitate cross-border payments and also share best practices and skills from time to time. Hence, he uses his previous relationships and experiences to advance the interest of the bank. However, he elaborated that there is always the negative image that is associated with Somalia and as such, sometimes even key relationships will shy away from supporting to establish strategic partnerships.

Case 4 - Premier Bank: According to Mr. Ahmed, he has been in the field of banking for more than 24 years. He has solid technical and managerial experience in the areas of banking operations, strategic business development, corporate, credit, and retail banking. He worked with Kenya Commercial bank (KCB) as a trainee as well as an expatriate of KCB in Tanzania. Mr. Ahmed joined the East Africa bank in Djibouti heading the Business \& Operations unit. He then joined Gulf African bank (Kenya) heading the Commercial banking department. Mr. Ahmed joined the International Commercial bank (ICB) in South Sudan as the Deputy Managing Director.

Mr. Ahmed has close relations with the Kenya Bankers Association (KBA). Mr. Ahmed is a CIB in Accountancy \& Management. Mr. Ahmed maintains a professional relationship with the central bank of Somalia as a regulatory body. Mr. Ahmed argues that there are extensive opportunities in Somalia and the world needs to consider these opportunities. He adds that Somalia is moving in the right direction and the banking industry has positively impacted the economy of the country. Mr. Ahmed had utilized his international experience and contacts to further the relational building of Premier bank. However, he 
stated that several challenges are hindering their attempt to establish ties with strategic partners such as the perceived country and financial risks.

\section{Implications}

Proposition 1 - Internationalisation \& Relations with Strategic Partners: International experience is very important in terms of building strategic partners. As per the argument of Daily, Certo, and Dalton (2000), executives should poses an international experience so that they can develop strategic partners and networks. The findings imply that Somali Banks should acquire executives with international experience if they are willing to establish strong ties with their strategic partners. As discussed in the literature review, international experience is among the critical components that are necessary for building organizational partners. Executives with international experience usually possess better perspectives, know-how, and strong network ties (Ancona \& Caldwell, 1992; Lee \& Park, 2008). For organizations to acquire critical and potential resources, they should employ executives with international experience.

Ahn et al. (2009), revealed that partnership usually tends to be embedded in a person's network and the organizations can develop new network alliances with the help of such a person's experience. The empirical data in this study shows that Premier Bank and International Bank of Somalia have established relations with strategic partners such as MasterCard, Visa card as compared to Dahabshiil International Bank and Amal bank. This had led them to offer international debit cards whereby their customers can access their accounts internationally. The reason behind this achievement is related to the international experience of the executives who are in charge of building strategic partnerships.

As per the analysis of the empirical data, we conclude that Proposition 1 is supported strongly. The proposition is backed by the fact that organizations employed executives with international exposure have secured partnerships with strategic financial institutions. Therefore, banks in Somalia should acquire executives with international exposure to establish relations with a strategic partner.

Proposition 2 - Social Network Heterogeneity \& Relations with Strategic Partners: This proposition discusses the importance of executives' social network heterogeneity when building organizational strategic partners. The heterogeneity of the networks is beneficial to organizations during their journey to establish strong ties with strategic partners. It will support creativity and innovation. According to Fang et al. (2012), network heterogeneity will allow executives to get broader information and knowledge whereby they will compare a range of options and discover further opportunities.

The empirical data in this study shows that executives of Premier Bank and International Bank of Somalia have a more heterogeneous network whereby they are members of professional entities and banker associations outside Somalia as compared to executives of Dahabshiil International and Amal banks. Indeed, this had played a role in building organizational partners. Based on this analysis, proposition 2 is supported strongly. The proposition is backed by the fact that organizations employed executives with the heterogeneous network have secured partnerships with strategic financial institutions. Therefore, banks in Somalia should acquire executives with a heterogeneous social network to establish relations with strategic partners. 
The discussion of this study yielded recommendations that are relevant for Somali Bankers as well as the policymakers. Due to the importance of international experience in building organizational strategic partners, Somali banks should recruit executives with international exposure in the banking industry. This will increase the chances of building organizational strategic partners. Moreover, executives with international experience are likely to have connections with their international peers hence the flow of information is improved. In addition to that, the social network of the executives with international experience may facilitate the exchange of information that is related to exploiting new opportunities thereby organizations can improve their performance. As per proposition 1, Banks should acquire executives with international exposure so that they develop organizational strategic partners.

Furthermore, the discussion of this study concludes that the heterogeneity of the executives' social network may influence the development of the organizational strategic partners. This will allow executives to get broader information and knowledge hence they compare a range of options and discover the best alternative as well as further opportunities. Based on proposition 2, Somali banks should recruit executives with a heterogeneous social network.

Finally, the discussion of this study revealed that other factors affect the efforts of the Somali banks towards building organizational strategic partners. Among these factors are; the functionality of the central bank, the id system of the country, security, The Judiciary system, and the overall image of the country. Based on this discussion, the government of Somalia should consider these aspects as challenges to the reconstruction and economic recovery of the country therefore a priority concern should be given.

Our study, like every research, has some limitations. Since the study was carried out with qualitative data collection techniques, the significance of the relationships between variables may be affected. Although our hypotheses have been substantially confirmed, this handicap may apply to unconfirmed hypotheses. If it is supported by quantitative data collection technique with a larger sample, improvement in the findings can be expected.

\section{Limitations and Future Implications}

Our study, like every research, has some limitations. Since the study was carried out with qualitative data collection techniques, the significance of the relationships between variables may be affected. Although our hypotheses have been substantially confirmed, this handicap may apply to unconfirmed hypotheses. If it is supported by quantitative data collection technique with a larger sample, improvement in the findings can be expected.

\section{References}

Ahn, K., Heewon, C., Jaeyong, S., \& Theresa, S. C. (2009). The effects of founder-ceo attributes on alliance formation of venture start-ups: a social network perspective. Paper read at Academy of Management Proceedings, 1-29. https://doi.org/10.5465/ambpp.2009.44257658

Ancona, D. G., \& Caldwell, D. F. (1992). Demography and Design: Predictors of New Product Team Performance. Organization Science, 3, 321-341. https://doi.org/10.1287/orsc.3.3.321

Balkundi, P., \& Kilduff, M. (2006). The ties that lead: A social network approach to leadership. The Leadership Quarterly, 17(4), 419-439. https://doi.org/10.1016/j.leaqua.2006.01.001 
Barnir, A., \& Smith, K. A. (2002). Interfirm alliances in the small business: The role of social networks. Journal of small Business management, 40(3), 219-232. https://doi.org/10.1111/1540-627X.00052

Cavusgil, S. T. (1998). Executive insights: International partnering-A systematic framework for collaborating with foreign business partners. Journal of International Marketing, 6(1), 91-107. https://doi.org/10.1177/1069031X9800600109

Daily, C. M., Certo, S. T., \& Dalton, D. R. (2000). International Experience in the Executive Suite: The Path to Prosperity? Strategic Management Journal, 21(4), 515-523. https://doi.org/10.1002/(SICI)1097-0266(200004)21:4<515::AID-SMJ92>3.0.CO;2-1

Davis, G. F., \& Cobb, J. A. (2010). Resource dependence theory: Past and future. In Stanford's organization theory renaissance, 1970-2000. Emerald Group Publishing Limited. 1- 31.

El-Khatib, R., Fogel, K., \& Jandik, T. (2015). CEO network centrality and merger performance. Journal of Financial Economics, 116, 349-382. https://doi.org/10.1016/j.jfineco.2015.01.001

Essman, C. (2015). Social preconditions of collective action among NGO: s: A social network analysis of the information exchanges between 55 NGO: s in Georgia. Sociologiska Institutionen Research Report.

Fang, Y., Francis, B., \& Hasan, I. (2012). More than Connectedness - Heterogeneity of CEO Social Network and Firm Value. Bank of Finland Research Discussion Papers, 26. http://doi.org/10.2139/ssrn.2172767

Fernández-Pérez, V., Jesús García-Morales, V., \& Fernando Bustinza-Sánchez, Ó. (2012). The effects of CEOs' social networks on organizational performance through knowledge and strategic flexibility. Personnel Review, 41(6), 777-812. https://doi.org/10.1108/00483481211263719

Freeman, L. (2004). The development of social network analysis. A Study in the Sociology of Science, 1(687), 159-167.

Gall, R. G., \& Schroder, B. (2006). Agricultural producer cooperatives as strategic alliances. International Food and Agribusiness Management Review, 9(4), 26-44.

Geletkanycz, M. A., Boyd, B. K., \& Finkelstein, S. (2001). The Strategic Value of CEO External Directorate Networks: Implications for CEO Compensation. Strategic Management Journal, 22(9), 889-898. https://doi.org/10.1002/smj.172

Gulati, R., Dialdin, D., \& Wang, L. (2002). Organizational Networks. In. J. A. C. Baum (Ed.), Blackwell Companion to Organizations (pp. 281-303). Blackwell. https://doi.org/10.1002/9781405164061.ch12

Harkins, J., \& Forster, N. (2014). Resource dependence and the exits of young firms. Entrepreneurship Research Journal, 4(4), 323-349. https://doi.org/10.1515/erj-2013-0063

Heimovics, R. D., Herman, R. D., \& Jurkiewicz Coughlin, C. L. (1993). Executive Leadership and Resource Dependence in Nonprofit Organizations: A Frame Analysis. Public Administration Review, 53(5), 419-427. https://doi.org/10.2307/976342

Jenssen, J. I., \& Koenig, H. F. (2002). The effect of social networks on resource access and business start$\begin{array}{llll}\text { ups. } & \text { European } & \text { Planning } & \text { Studies, }\end{array}$ https://doi.org/10.1080/0965431022000031301

Kirchmaier, T., \& Stathopoulos, K. (2008). From fiction to fact: The impact of CEO social networks (No. 537). Manchester Business School Working Paper. http://hdl.handle.net/10419/50720

Knoke, D., \& Yang, S. (2019). Social network analysis, 154. SAGE Publications. https://doi.org/10.4135/9781506389332

Lee, H. U., \& Park, J. H. (2008). The influence of top management team international exposure on international alliance formation. Journal of Management Studies, 45(5), 961-981. https://doi.org/10.1111/j.1467-6486.2008.00772.x

McDonald, M. L., \& Westphal, J. D. (2003). Getting by with the advice of their friends: CEOs' advice networks and firms' strategic responses to poor performance. Administrative science quarterly, 48(1), 1-32. https://doi.org/10.2307/3556617

Milanzi, M. A. (2012). Export barrier perceptions in Tanzania: The influence of social networks. Journal of African Business, 13(1), 29-39. https://doi.org/10.1080/15228916.2012.657941 
Okello Candiya Bongomin, G., Ntayi, J. M., Munene, J. C., \& Malinga, C. A. (2018). Mobile money and financial inclusion in sub-Saharan Africa: the moderating role of social networks. Journal of African Business, 19(3), 361-384. https://doi.org/10.1080/15228916.2017.1416214

Pfeffer, J., \& Salancik, G. R. (1978). The External Control of Organizations: A Resource Dependence Perspective. University of Illinois at Urbana-Champaign's Academy for Entrepreneurial Leadership Historical Research Reference in Entrepreneurship. https://ssrn.com/abstract=1496213

Sapat, A., Esnard, A.-M., \& Kolpakov, A. (2019). Understanding Collaboration in Disaster Assistance Networks: Organizational Homophily or Resource Dependency? The American Review of Public Administration, 49(8), 957-972. https://doi.org/10.1177/0275074019861347

Von Berg, M. (2016). Economic solutions are crucial to help solve Somalia's political woes. Africa at LSE. https://blogs.lse.ac.uk/africaatlse/2016/11/02/economic-solutions-are-crucial-to-help-solvesomalias-political-woes

Waddock, S. A. (1989). Understanding social partnerships: An evolutionary model of partnership $\begin{array}{llll}\text { organizations. Administration } \quad \& \quad \text { Society, } & \text { 21(1), }\end{array}$ https://doi.org/10.1177/009539978902100105

Walther, O. J. (2014). Trade networks in West Africa: A social network approach. The Journal of Modern African Studies, 52(2), 179-203. https://doi.org/10.1017/S0022278X14000032

Zhang, J. (2019). Executive Social Network and Enterprise Innovation. Journal of Accounting, Business and Finance Research, 7(1), 17-23. https://doi.org/10.20448/2002.71.17.23 